\title{
Artikkeli
}

Prologi - puheviestinnän vuosikirja 2019

22-35

https://doi.org/10.33352/prlg.80529

\section{"No periaatteessa minun tiedossani se aika lailla on": Palveluohjauksen työntekijän tiedollinen asema varhaiskasvatuksen palveluohjauskeskusteluissa}

\author{
Anu Kuukka \\ KT, Tutkijatohtori \\ Jyväskylän yliopisto \\ Kasvatustieteiden laitos \\ anu.kuukka@jyu.fi
}

\author{
Anna Siippainen \\ KT, Yliopistonlehtori \\ Tampereen yliopisto \\ Kasvatustieteiden ja kulttuurin tiedekunta \\ anna.siippainen@tuni.fi
}

\author{
Maarit Alasuutari \\ Professori \\ Jyväskylän yliopisto \\ Kasvatustieteiden laitos \\ maarit.alasuutari@jyu.fi
}

\section{Tiivistelmä}

Kunnilla on laissa säädetty velvollisuus antaa huoltajille tietoa erilaisista varhaiskasvatuksen vaihtoehdoista. Tätä tiedottamista kutsutaan palveluohjaukseksi. Tässä artikkelissa tarkastellaan huoltajan ja kunnan palveluohjauksen työntekijän välisiä puhelinkeskusteluja. Palveluohjauskeskusteluja tutkitaan institutionaalisen vuorovaikutuksen näkökulmasta. Institutionaaliselle vuorovaikutukselle on ominaista osallistujien roolien muotoutuminen vuorovaikutuksen edetessä (esim. Drew \& Heritage, 1992). Artikkelissa kiinnitämme huomion vuorovaikutukseen osallistujien tiedollisiin suhteisiin hyödyntämällä tietämisen alueen käsitettä (Heritage, 2012). Artikkelissa tutkitaan, miten palveluohjauksen työntekijän tiedollinen asema rakentuu vuorovaikutuksessa huoltajan kanssa ja minkä tiedon tulkitaan keskusteluissa kuuluvan työntekijän tietämisen alueeseen. Aineisto koostuu varhaiskasvatuksen palveluohjauksen puhelinkeskustelujen tallenteista $(n=24)$, joiden analyysi pohjaa diskurssianalyyttiseen tarkasteluun. Työntekijän tietämisen alueen kuvataan muodostuvan tiedon tarjoamisen, tiedonannon vaiheittaisuuden ja tietämisen oikeutuksen kokonaisuudesta. Tiedon tarjoaminen ja samalla työntekijän ammatillisen tietämisen alue käsitti kunnan varhaiskasvatuspalveluita koskevan perustiedon. Lisäksi siihen katsottiin kuuluvan huoltajien työtilanne, minkä seurauksena puhelinkeskusteluja sävytti työelämäorientoituneisuus. Sen sijaan niihin ei juurikaan sisältynyt keskustelua lapsesta.

ASIASANAT: diskurssinanalyysi, institutionaalinen vuorovaikutus, palveluohjaus, varhaiskasvatus, vuorovaikutuksen tutkimus 


\section{Johdanto}

Kun huoltajat pohtivat varhaiskasvatusikäisen lapsensa hoitoratkaisua, he ovat yleensä yhteydessä oman asuinkuntansa varhaiskasvatuksen viranhaltijaan. Yhteyttä otetaan tavallisesti siinä vaiheessa, kun lastenhoidon järjestelyissä on tapahtumassa muutoksia. Varhaiskasvatuksen toimintaa sitovasti ohjaavassa Varhaiskasvatussuunnitelman perusteissa todetaan seuraavasti:

"On tärkeää, että huoltajat saavat riittävästi tietoa kaikkien toimintamuotojen sisällöistä ja ominaispiirteistä. Kunnan on järjestettävä ohjausta ja neuvontaa huoltajille tarjolla olevista varhaiskasvatuspalveluista. Tarvittaessa huoltajan kanssa keskustellaan siitä, mikä varhaiskasvatuksen toimintamuoto ja laajuus vastaavat lapsen tarpeita ja etua. Neuvontaa ja ohjausta annetaan varhaiskasvatuspalveluihin hakeuduttaessa, sekä lapsen jo ollessa palvelujen piirissä." (Opetushallitus, 2018, s. 18.)

Tätä perheiden kanssa käytävää neuvottelua ja tiedottamista kuvataan termillä palveluohjaus. Tässä artikkelissa tarkastelemme huoltajan ja varhaiskasvatuksen viranhaltijan välisiä palveluohjauskeskusteluja erityisesti työntekijän tiedollisen aseman ja tietämisen näkökulmasta. Tutkimuksemme on osa Strategisen tutkimuksen neuvoston Tasa-arvo ja yhteiskunta -ohjelman rahoittamaa CHILDCARE-hanketta (SA 293049).

Varhaiskasvatuspalvelujen palveluohjauksella ei ole tarkkaa määritelmää. Palveluohjauksen käsitettä käytetään myös esimerkiksi sosiaalityössä, jossa käsitteellä tarkoitetaan erilaisia palveluja tarvitsevan asiakkaan elämänhallinnan tukemista ja palvelujen koordinointia, usein pitkällä aikajänteellä (esim. Hänninen, 2007, s. 12). Varhaiskasvatuksen palveluohjauksen voi sen sijaan nähdä tarkoittavan lyhy- taikaisempaa kaikille lapsiperheille tarkoitettua neuvontaa ja ohjausta heidän käytettävissään olevista varhaiskasvatuspalveluista (Varhaiskasvatuslaki 540/2018, \$16). Palveluohjauksen toisena merkittävänä tehtävänä voidaan pitää perheiden tarpeiden kartoittamista. Varhaiskasvatuslain (540/2018) mukaan kunnan on järjestettävä varhaiskasvatusta "siinä laajuudessa ja sellaisin toimintamuodoin kuin kunnassa esiintyvä tarve edellyttää”. Ideaalitilanteessa ohjauksen myötä asiakas ja palveluohjauksen työntekijä löytävät kunkin perheen tarpeita parhaalla mahdollisella tavalla vastaavan lastenhoidon ratkaisun (myös HE 80/2015).

Palveluohjaus toteutuu yleensä tilanteessa, jossa lapsi on siirtymässä ensimmäistä kertaa varhaiskasvatuspalveluiden piiriin, mutta hallituksen esityksen mukaisesti (HE 80/2015) varhaiskasvatuspalveluiden aloittamisen ajankohdan lisäksi palveluohjausta voidaan antaa myös esimerkiksi perheen tilanteen tai hoidon tarpeen muuttuessa. Käytännössä kunnissa ohjauksen tavat ja toteuttajat vaihtelevat suuresti. Palveluohjausta saattavat tarjota niin päiväkotien johtajat kuin varhaiskasvatuksen vastaavat viranhaltijat. Palveluohjaus on myös saatettu keskittää tietyille nimetyille henkilöille. Palveluohjausta annetaan esimerkiksi henkilökohtaisin keskusteluin, puhelimitse tai sähköpostilla. Joissain kaupungeissa on käytössä myös verkkosivuilta löytyvä mahdollisuus chat-keskusteluun ohjauksesta vastaavan henkilön kanssa.

Tässä artikkelissa tarkastelemme huoltajan ja palveluohjauksen työntekijän välisiä puhelinkeskusteluita. Tutkimme niitä institutionaalisen vuorovaikutuksen näkökulmasta. Institutionaaliselle vuorovaikutukselle on ominaista osallistujien asemien muotoutuminen vuorovaikutuksen kulussa. Toisin sanoen sitä kehystävät tietynlaiset tulkinnat osallistujien toiminnasta ja käyttäytymisestä, niiden mahdollisuuksista 
ja rajoista. Lisäksi institutionaalista keskustelua luonnehtii ainakin yhden osapuolen tehtävätai tavoiteorientaatio (Drew \& Heritage, 1992, s. 21-25; Wintermantel, 1991, s. 126).

\section{Institutionaalisen vuorovaikutuksen epäsymmetrisyys}

Institutionaaliselle keskustelulle on ominaista osapuolten tiedollinen epäsymmetria (Stevanovic \& Peräkylä, 2012). Tyypillisesti instituution edustajalla eli asiantuntijalla on enemmän tietoa kuin vuorovaikutuksen toisella osapuolella. Tämän epäsymmetrian arkinen ilmentymä voi olla ammattikieleen liittyvien erikoistermien käyttö keskustelussa (esim. Raevaara, Ruusuvuori, \& Haakana, 2001). Teoreettisesti institutionaalisen vuorovaikutuksen epäsymmetriaa voi lähestyä episteemisyyden ja deonttisuuden käsitteiden kautta. Episteemisillä eli tiedollisilla suhteilla tarkoitetaan sitä, miten vuorovaikutukseen osallistujat asemoivat itsensä ja toisensa keskusteltavan asian suhteen joko enemmän tai vähemmän tietäviksi tai tietämättömiksi. Kyse on yhtäältä siitä, kuka tietää mitäkin. Toisaalta kyse on myös siitä, kenellä on oikeus ja velvollisuus ilmaista tietämystään kenellekin ja millaisessa tilanteessa, kenellä taas ei. (Stevanovic, 2016; Stevanovic \& Peräkylä, 2012.) Deonttisuus taas liittyy siihen, millä tavoin keskustelun osapuolet voivat toimia tulevan toiminnan auktoriteetteina ja tehdä esimerkiksi ehdotuksia siitä, mitä keskustelukumppanin tulisi tai olisi hyvä tehdä (Stevanovic \& Peräkylä, 2012).

Deonttisuuden käsite liittyy siten neuvomisen tematiikkaan institutionaalisessa vuorovaikutuksessa. Varhaiskasvatuksen palveluohjauksessa - kuten monessa muussa ihmissuhdetyössä - neuvojen antaminen ja niiden pyytäminen ovat keskeisessä roolissa jo toiminnalle asetettujen virallisten tavoitteiden vuoksi. Vuorovai- kutuksessa neuvon antaja asemoituu sellaisen tiedon omaavaksi, jota neuvon saajalla ei ole. Neuvon pyytäjä taas asettaa keskustelukumppaninsa asiantuntijan asemaan ja asemoituu itse neuvottavaksi. Neuvon antaminen voi tapahtua myös pyytämättä. Neuvon tarpeen voi tulkita tällöin syntyneen esimerkiksi osana edeltävää vuorovaikutusta. (Butler, Potter, Danby, Emmison, \& Hepburn, 2010; Vehviläinen, 2001.) Vaikka neuvon antaminen ja kysyminen asettavat vuorovaikutuksen osapuolet lähtökohtaisesti epäsymmetriseen asemaan, on huomioitava, että vuorovaikutus on jatkuvaa neuvottelua asemista. Neuvon saaja voi vastustaa neuvoa tai hylätä sen samoin kuin henkilö, jolta neuvoa kysytään, voi kieltäytyä neuvon antamisesta. (Hepburn \& Potter, 2011; Stevanovic \& Peräkylä, 2012; Vehviläinen, 2001.) Tällöin neuvomisen tilanteen tiedolliset asemat muuttuvat.

Tässä artikkelissa olemme kiinnostuneita edellä kuvatuista institutionaalisen vuorovaikutuksen episteemisistä ja deonttisista ulottuvuuksista erityisesti siitä näkökulmasta, miten ne ilmenevät työntekijän toiminnassa varhaiskasvatuksen palveluohjauskeskusteluissa. Sen lisäksi, että kiinnitämme huomiomme siihen, miten työntekijän tiedollinen asema rakentuu vuorovaikutuksessa huoltajan kanssa, erittelemme sitä, minkä (asiakkaan omaavan) tiedon tulkitaan keskusteluissa kuuluvan työntekijälle. Käytämme artikkelissamme näistä tulokulmista käsitettä palveluohjauksen työntekijän tietämisen alue. John Heritagea (2012) mukaillen tietämisen alue käsittää sen, mitä keskusteltavasta asiasta tiedetään, miten tiedetään sekä vuorovaikutukseen osallistuvien oikeudet ja velvollisuudet tietää asiasta. (Heritage, 2012.) Kysymme siten, millaiseksi työntekijän tietämisen alue muodostuu varhaiskasvatuksen palveluohjauksen puhelinkeskusteluissa? 
Ymmärrämme tietämisen alueen vuorovaikutuksessa rakentuvaksi ja siten vaihtelevaksi ja muuttuvaksi keskustelun kuluessa. Lisäksi tietämisen alueet eivät ole toisiaan poissulkevia. Vaikka keskustelun osapuolilla on omat tietämisen alueensa, tietyt seikat voivat sisältyä kummankin osapuolen alueelle, joskin tavallisesti eriävissä määrin. Tietäminen voi siten vaihdella eri astein tilanteesta, jossa henkilöllä A on varma tieto jostain aiheesta, kun taas henkilöllä B kyseistä tietoa ei ole, tilanteeseen, jossa molemmilla henkilöillä on täysin yhtäläinen tieto. (Heritage, 2012.) Esimerkiksi institutionaalisessa vuorovaikutuksessa asiantuntijalla voi olettaa olevan yleis- ja erityistietämystä instituutiosta ja sen tarjoamista palveluista, kun taas asiakkaan tietämyksessä voivat painottua hänen henkilökohtaiset kokemuksensa ja elämäntilanne (Lindström \& Karlsson, 2016). Julkisen sektorin organisaatiossa esimiehen ja alaisen välisiä kehityskeskusteluja analysoinut Mikkola (2015) havaitsi alaisen asemoituvan erityisasemaan hänellä olevan ensisijaisen, hänen työtehtäviinsä liittyvän tiedon perusteella, vaikka esimiehelle tulkittiin kuuluvan tiettyjä institutionaalisia oikeuksia deonttisen asemansa vuoksi.

\section{Tutkimuksen menetelmälliset ratkaisut ja aineiston kuvaus}

Tämän tutkimuksen aineistona käytetään huoltajan ja kunnan palveluohjauksen työntekijän välisten puhelinkeskustelujen tallenteita. Palveluohjausta antavat henkilöt työskentelivät tutkimuskunnissa varhaiskasvatuksen hallinnollisissa tehtävissä. Puheluissa huoltaja lähestyi työntekijää joko ensimmäisen kerran tai huoltaja ja työntekijä palasivat jo aikaisemmin käytyyn keskusteluun. Viimeksi mainitussa tilanteessa työntekijä oli useimmiten soittanut huoltajalle. Hän saattoi esimerkiksi tarkistaa puhelussa joitain tietoja huoltajalta ja esitellä tälle suunnittelemansa päätöksen lapsen varhaiskasvatuspaikasta. Tutkijoista kukaan ei ollut henkilökohtaisesti paikalla, kun aineistoja kerättiin, vaan palveluohjausta antavat työntekijät tallensivat keskustelut huoltajan luvalla.

Tutkimusta varten oli haettu tutkimuslupa kuntien sivistystoimesta. Palveluohjauskeskusteluja koskevasta aineiston keruusta oli myös tiedote kuntien varhaiskasvatuspalvelujen verkkosivuilla. Lisäksi työntekijät esittelivät tutkijoilta saadun kirjallisen ohjeistuksen pohjalta huoltajille tutkimuksen tarkoitusta ja puhelintallenteina kerättävän aineiston osuutta osana CHILDCARE-tutkimusta. Samalla työntekijät toivat esille osallistumisen vapaaehtoisuuden sekä tiedustelivat suullisesti huoltajien suostumusta keskustelun tallentamiseksi. Tallennus käynnistettiin vasta, jos huoltaja oli antanut luvan siihen.

Yhteensä puhelinkeskusteluja tallennettiin 26 kappaletta kahdessa kunnassa. Tallennus tapahtui syksyllä 2017. Osassa keskusteluja tallennus epäonnistui siten, että ainoastaan työntekijän puhe tallentui kunnolla. Näistä keskusteluista on otettu mukaan ainoastaan ne, joissa on riittävästi osia myös huoltajan puheesta, jotta keskustelun kulkua pystyy seuraamaan. Analyysin kohteena on näin ollen 24 keskustelua. Tallenteiden kestot vaihtelivat reilusta minuutista 15 minuuttiin, ja yhteensä aineistoa kertyi 166 minuutin verran. Keskimääräinen puhelu kesti noin 6 minuuttia (6 min $9 \mathrm{~s}$ ). Puhelinkeskustelujen taltioinnit kirjoitettiin sanatarkasti tekstiksi huomioiden tauot ja puhenopeuden vaihtelut. Litteroitua tekstiä kertyi kaikkiaan 55 sivua (Verdana, kirjasinkoko 8, rivinväli 1). Henkilöitä koskevat tiedot muutettiin siten, ettei yksittäisiä huoltajia, perheitä, työntekijöitä tai kuntia voi tunnistaa. Tulososiossa esitettyjen aineisto-otteiden litterointimerkkien selitykset ovat artikkelin liitteenä (liite 1). 
Puhelinkeskustelujen analyysi pohjaa diskurssianalyyttiseen tarkasteluun (Edwards \& Potter, 1992; Potter \& Hepburn, 2007), jossa keskeistä on kielenkäytön seurauksien erittely. Diskurssianalyysissä kielenkäyttö ymmärretään toimintana, jolla rakennetaan sosiaalista todellisuutta. Kiinnostus suuntautuu etenkin ihmisten välisessä vuorovaikutuksessa ilmeneviin kulttuurisiin merkityssisältöihin, siihen mitä kielenkäytöllä tehdään ja mitä sillä saadaan aikaan keskustelun vuorovaikutuksen kulussa. (Jokinen, Juhila, \& Suoninen, 2016.) Huomio kohdentuu myös siihen, millainen asema vuorovaikutukseen osallistuville muodostuu puheessa ja suhteessa toisiinsa (Alasuutari, 2010; Jokinen, Juhila, \& Suoninen, 2016). Puheen merkitystä ei voida tulkita ilman, että sen vuorovaikutuksellinen konteksti otetaan huomioon. Vuorovaikutuksen kulku, se mitä on aiemmin sanottu ja mitä sen jälkeen sanotaan, osoittaa kuinka osapuolet suhtautuvat ja vastaavat toistensa puheeseen ja minkä merkityksen puhe saa. (Esim. Jokinen, Juhila, \& Suoninen, 2016; Molder, 2015.)

Aineiston analyysi eteni teoreettisten käsitteiden ja empirian vuoropuheluna. Jacksonin ja Mazzein (2012) mukaisesti aineistolle esitettiin erityisesti episteemisyyden ja deonttisuuden käsitteiden ja aikaisemman tutkimustiedon pohjalta analyyttisiä kysymyksiä. Aineiston luennassa huomiomme kiinnittyi ensin palveluohjauksen työntekijän ja huoltajan välisessä keskustelussa toistuviin piirteisiin. Tällaisia toistuvia piirteitä olivat muun muassa yhtäältä työntekijän tiedon antaminen huoltajalle ja toisaalta vastaamisen ja tiedon antamisen välttäminen huoltajan esittäessä kysymyksen sekä työntekijän huoltajalle esittämät kysymykset. Nämä toistuvat piirteet olivat tulkittavissa tietämisen ja asiantuntijuuden tematiikkaan liittyviksi, minkä vuoksi kohdensimme alustavan analyysimme niihin. Tämän jälkeen erit- telimme vuorovaikutuksen kulkua episodeittain, joiden rajaksi tulkitsimme keskustelun teeman vaihtumisen. Sisällöllisesti episodeissa käsiteltiin etupäässä lapsen hoitoaikoja ja vanhemman työaikoja, perhetilannetta, palvelujen saatavuutta ja maksuihin sekä hakuprosessiin liittyviä asioita. Ensi alkuun erittelimme sekä huoltajan että työntekijän asemoitumisia tietämisen ja tiedon osalta episodeittain, mutta tutkimuksen fokusoimiseksi päädyimme rajaamaan tutkimuskysymyksemme pelkästään työntekijän asemaa koskeviksi. Analyysissä olennaista oli, että tarkastelimme eri puheenvuoroja aina vuorovaikutuskontekstissaan.

Jäsensimme havaintojamme koodaamalla työntekijän tietämisen asemia erilaisiin - ja analyysin kuluessa vaihtuviin - luokkiin. Lopulta ryhmittelimme episodit kolmeen tyyppiin: 1) episodeihin, joissa työntekijä asemoi itsensä asiantuntijaksi ja antaa suoraan tietoa huoltajalle, 2) episodit, joissa työntekijän tiedon tarjoaminen huoltajalle tapahtuu vaiheittain sekä 3) episodeihin, joissa työntekijä hakee tietoa huoltajalta. Näiden kolmen tyypin kautta rakentuu työntekijän tietämisen alue ja sen rajat tutkimusaineistossamme.

\section{Palveluohjauksen työntekijän tietämisen alue}

Tutkimusaineistossa toistuvana piirteenä on työntekijä selostus kunnan varhaiskasvatuspalveluista. Työntekijät kertovat huoltajille puhelinkeskusteluissa tyypillisesti kunnassa ja lähialueella tarjolla olevista lastenhoito- ja varhaiskasvatuspalveluista, vapaista hoitopaikoista ja ryhmärakenteista, hakemisen menettelystä, asiakasmaksuista ja niiden perusteista. Samalla kun palveluja koskevan informaation esittämisen voi ajatella olevan työntekijän työn keskeistä sisältöä, vaihtelevat tavat, joilla he antavat tätä tietoa. Lisäksi työntekijät osoittavat 
vanhemmille esittämillään kysymyksillä tiettyjen asioiden itsestään selvästi kuuluvan omaan tietämisen alueeseensa.

\section{Tiedon tarjoaminen huoltajalle}

Palveluohjauksen tehtävään keskeisesti liittyvä informaation tarjoaminen saattaa tapahtua ilman, että vanhempi kysyy palveluista, esimerkiksi kun työntekijällä on jo tieto ilmeisesti huoltajan jättämän hakemusdokumentin perusteella toivotusta hoitomuodosta, -ajasta ja -paikasta. Palveluihin liittyvät kysymykset ovat kuitenkin niitä, joita huoltajat myös erityisesti kysyvät työntekijöiltä. Seuraava aineisto-ote kuvaa tilannetta, jossa työntekijä vastaa huoltajan tiedusteluun lapsiryhmistä. Otetta edeltävässä keskustelussa on käynyt ilmi, että perheen ensisijaisesti toivomissa päiväkodeissa lapsiryhmät ovat täynnä tai vapaana olevat paikat ovat lapsen ikään nähden epäsopivissa ryhmissä. Työntekijä ehdottaa perhepäivähoitoa. Huoltaja jatkaa tiedustelemalla eri päiväkotien ryhmävaihtoehtoja.

\section{Aineisto-ote 1}

H: Niin mul on se ajatus sijottaa joku tämmönen sitä hakemusta tehdessä ku se on 1-3-vuotiaitten se (--) johonkin (--) ryhmiä niin, (--)

TT: [---] Et periaatteessa tää päiväkotimatematiikkahan menee niin et jos sul on ryhmässä kaikki alle kolmevuotiaita niin siin ryhmäs on 12 lasta ja se on täynnä kun semmonen alle kolmevuotias vie sielt ryhmästä laskennallisesti 1.75 hoitopaikkaa (2) mut sit jos siin on kyseessä ryhmä jossa on jo tota noin niin kolme vuotta täyttäneitä niin nää kolmevuotiaat viel sielt sit vaan enää yhden paikan (1) ja sillon se ryhmäkoko saattaa kasvaa, elikkä meil esimerkiks on nyt alueella on semmosii yksiköitä joissa on on sekä pieniä että isoja niin siin ryhmäs voi olla vaikka 16 lasta, ja tota, se riippuu aina siit miten se ryhmä siihen päiväkotiin muodostuu.

Työntekijän vastauksessa tulee esille hänen lapsiryhmien koon perusteiden tarkka tuntemus. Tämänkaltainen ammatillinen tieto näyttäytyy tutkimusaineistossa hyvin itsestään selvästi työntekijän tietämisen alueeseen kuuluvaksi. Se keskittyy erityisesti varhaiskasvatuspalveluiden saatavuuteen ja tarjontaan sekä hakuprosessiin. Vanhemmat eivät yleensä tuo esiin tietoaan näistä seikoista, vaan kysyvät niitä työntekijältä. Ammatillisen tiedon voi ajatella perustuvan varhaiskasvatuksen järjestämistä ohjaaviin lakeihin ja asetuksiin, mutta myös kuntien omiin säädöksiin ja ohjeistuksiin.

Osa työntekijän tietämisen alueelle paikantuvasta tiedosta on myös huoltajan ulottuvilla, vaikkapa luettavissa vapaasti kunnan nettisivuilta. Mielenkiintoisen seikan aineistossa muodostavatkin episodit, jossa työntekijät ohjaavat vanhemman itse ottamaan selvää asioista, joiden voi olettaa lähtökohtaisesti kuuluvan heidän tietämisen alueelleen. Nämä episodit liittyvät usein varhaiskasvatuksen asiakasmaksuperusteisiin, jotka määräytyvät lapsen hoitoajan ja perheen tulotason mukaan.

\section{Aineisto-ote 2}

H: [---] Ja sit siin oli siin ajasta ni me ollaan sillai et, hän tulee varmaan olemaan aika sillai epäsäännöllisesti siel, et koska meil on nyt sit viel sillai et (1) kun mä teen viikonlopputöitä nii me ollaan ajateltu et kyl hän nyt aikanki yhen päivän viikosta on kotona.

TT: Aivan, joo, elikkä oletko sä käyny yhtään kattomassa ku meil on ne tuntirajat (1) nyt sitte kuukaudessa? 
H: En, en oo mut, eiks siel ollu sillai et oliks se alle 35 ja alle 25 ?

TT: Joo ne on keskimäärin viikkotuntimäärät mut meillä on tota ihan kuukausituntimäärät elikkä

\section{H: Okei.}

TT: 80 tuntia kuukaudessa on se pienin. (1) se on keskimäärin neljä tuntia päivässä, ja 100 tuntia kuukaudessa on se seuraava, ja sit mennään siihen, et mikä varmaan sit teille riittäis se alle 139 tuntia kuukaudessa.

$\mathrm{H}$ : Joo mä mietin et paljoks se sit tekee, niinku niin alle 139 kuulostas silt et onks se sit niinku (1) mä en oo noit ollenkaan tiennykään et alle sata.

TT: Joo elikkä se on tota noin niin, 80 prosenttia kokopäivämaksusta sillon (1) sä, sun kannattas varmaan meijän nettisivuilla käydä kattomassa. Siellä on asiakasmaksuperusteet niin siellä on.

H: Okei, no semmost mä en oo osannu kattookaan.

Aineisto-otteessa on kyse tilanteessa, jossa huoltaja tekee vuorotyötä. Ennen kuvattua otetta on käyty keskustelua molempien huoltajien työajoista, jossa huoltaja on tulkinnut työntekijän puhetta ainakin osin syyllistäväksi. Tätä ilmentää myös aineisto-otteessa huoltajan ensimmäinen puheenvuoro, jossa hän kertoo, että lapsi tulisi olemaan ainakin yhden päivän viikosta kotona. Samalla hän puolustautuu sitä tulkintaa vastaan, että lapsi tulisi olemaan liian paljon hoidossa vanhempien työn vuoksi. Tämän jälkeen työntekijä vaihtaa keskustelun aiheen tiedustelemalla, missä määrin huoltaja on ennalta perehtynyt hoitoaika- ja maksuperusteisiin. Kysymys on kaksinainen (Heritage, 2012). Sen lisäksi, että se edellyttää huoltajan vastauksen, kysymyksessä erityisesti sanan yhtään käyttäminen tuottaa odotuksen (ks. Tannen, 1993), että maksuperusteisiin tutustuminen on vanhemmalle oletettua toimintaa. Samalla kysymyksen voi tulkita antavan neuvon vanhemmalle, mitä hänen on hyvä tehdä jatkossa (myös Wintermantel, 1991, s. 134-135). Työntekijän viimeinen puheenvuoro aineisto-otteessa esittää saman ohjeen modaali-ilmaisulla kannattas varmaan. Ohjeellaan työntekijä siirtää vanhemmalle vastuuta maksuperusteisiin tutustumisesta samalla, kun hän yksityiskohtaisissa vastauksissaan osoittaa tuntevansa maksuperusteet tarkasti. Toisin ilmaistuna voi todeta, että maksuperusteet työntekijä tarjoaa sellaiseksi ammatillisen tietämyksen alueeksi, johon huoltajalla on oletettu pääsy ja joka siten kuuluisi myös huoltajalle.

Edellä kuvatussa keskustelussa työntekijä asemoituu asiantuntijaksi, jolla on yksityiskohtaista tietämystä hoitoaika ja -maksuperusteista sekä siitä, mikä kuukausituntimäärä voisi olla perheelle riittävä. Sen sijaan huoltajan tieto aiheesta osoittautuu puutteelliseksi. Pyytämällä työntekijältä tietoa ja ilmaisemalla oman tietämättömyytensä asiasta huoltaja sijoittaa työntekijän episteemisen auktoriteetin asemaan. Työntekijän neuvova puheenvuoro ilmentää samanaikaisesti sekä episteemistä että deonttista asemoitumista suhteessa huoltajaan, oikeutta ehdottaa ja määrätä huoltajan tulevaa toimintaa. Työntekijän deonttinen asema ei kuitenkaan asetu hänelle ilman, että huoltaja sallii hänelle tämän aseman tuomalla esille oman tietämättömyytensä ja osoittamalla hyväksyvänsä työntekijän ehdotuksen (myös Stevanovic, 2013). Työntekijän tietämiseen aluetta samoin kuin keskustelun osapuolten asemien erilaisuutta merkitään varhaiskasvatuksen palveluohjaukseen kontekstoituvalla ammattisanastolla asiakasmaksuperusteista, maksuluokista, tuntirajoista, viikko- ja kuukausituntimääristä ja portaista, joiden voi ajatella olevan huolta- 
jalle vieraampia termejä (myös Haakana ym., 2001).

Työntekijän antama neuvo muotoutui tutkimusaineistossa tavallisesti osana keskustelun kulkua huoltajan puutteellista tietämystä täydentämään. Huoltajat myös kysyivät työntekijältä neuvoa esimerkiksi lapsensa hoidon aloittamiseen liittyvissä erilaisissa käytännön asioissa. Toisinaan keskustelutilanne itsessään tuotti tulkinnan neuvomisen tarpeesta kuten seuraavassa, jossa huoltaja tuo esille lapsen hoidon aloittamiseen liittyvän huolensa.

\section{Aineisto-ote 3}

TT: ...On varmaan, hän on meijän pitkäaikasii kuitenki siis monta vuotta töitä tehneit hoitajia, että kyllä kyllä osaa varmasti olla niin pienen lapsen, niin [lapsen nimi] on täyttäny just vuoden?

H: Joo.

TT: Joo.

H: Mulla on tietty kauheen paha omatunto siitä.

TT: Niin joo (naurahtaen) joo.

H: (Vähä kuitenki) (--) kauheessa stressis ollu.

TT: Joo, hyvin se menee, siis onhan meil sillai et meil tulee osa ihan suoraan äitiyslomalt kymmenkuisena että tota...

H: Juu sitä noi neuvolatädit (--).

TT: Joo, kyllä juu juu juu, että ei oo vaihtoehtoja niin. Mutta ei, en usko että on sen suhteen mitään murhetta että tietyst lapset on erilaisia ja joillaki se alku kestää ja se totuttautuminen kestää vähän pidempään. Ja joillaki se menee nopeemmin mut monta kertaa se just voi olla äidille (naurahtaen) vähän kovempi paikka se alku että. Kannattaa alussa pistää isä viemään laps päivähoitoon niin pääsee itte helpommalla. [---]

Aineisto-ote kuvaa tilannetta, jossa perhe on saanut vuoden ikäiselle lapselleen paikan perhepäivähoidosta. Keskustelussa huoltaja kertoo kodin ulkopuolisen hoidon aloittamiseen liittyvästä huonosta omastatunnostaan ja stressistä. Huoltajan puheenvuoron voi tulkita sisältävän odotuksen vastauksesta. Työntekijä lieventää huoltajan huolta vastaamalla kaiken sujuvan hyvin ja esittämällä näkemyksensä siitä, kuinka pienten lasten varhaiskasvatuksen aloittaminen yleensä sujuu ja antamalla toimintaohjeen siitä, kuinka hoidon aloittamisen voisi toteuttaa. Vastaus ilmentää työntekijän tietämystä arvioida pienen lapsen hoidon aloittamiseen ja hyvinvointiin liittyviä kysymyksiä, mutta rajaa huoltajan henkilökohtaiset tuntemukset ulkopuolelle. Myös työntekijän puheenvuoroissa esiintyvät naurahdukset voi yhtäältä tulkita keinona hälventää vanhemman huolta, toisaalta naurahdus voi olla reaktio ongelmalliseksi koettuun aiheeseen (Alasuutari, 2010).

\section{Vaiheittainen tiedon antaminen huoltajalle}

Vaikka analysoimissamme palveluohjauskeskusteluissa työntekijät tyypillisesti osoittivat varhaiskasvatuspalveluiden saatavuuteen ja tarjontaan liittyvät tiedot omaksi tietämisen alueekseen ja informoivat vanhempia niistä, esiintyi joissakin keskusteluissa myös episodeja, joissa työntekijä ei ilmaissut kyseisiä tietoja suoraan, vaikka vanhempi niitä kysyi. Sen sijaan hän saattoi antaa vastauksen vanhemman kysymykseen vasta pitkähkön keskustelujakson jälkeen tai vaiheittain. Tämä kuvastaa tyypillistä virkailijan ja asiakkaan välistä vuorovaikutusta, jossa asiakkaan asian eteenpäin viemiseen tarvitaan monenlaisia tietoja sekä 
asiakkaan näkökulman ja virkailijan asiantuntemuksen yhteensovittamista (Raevaara, 2006).

Seuraavassa aineisto-otteessa yksivuotiaan lapsen huoltaja soittaa ensimmäistä kertaa kunnan palveluohjauksesta vastaavalle henkilölle saatuaan tiedon nopeasta työllistymisestään. Keskustelu alkaa huoltajan kysymyksellä hakuprosessin etenemisestä ja jatkuu siihen, mistä hän saisi tiedon vapaana olevista perhepäivähoidon paikoista. Tähän työntekijä vastaa: "No periaatteessa minun tiedossani se aika lailla on se perhepäivähoidon tilanne. Että sillon kun päivähoitohakemusta oot laatimassa niin sitä, hoidon järjestelyä voi toivoo...”. Työntekijän vastaus on siinä mielessä mielenkiintoinen, että hän toteaa tiedon perhepäivähoidon paikoista olevan hänellä itsellään, mutta ei kuitenkaan ala kertoa huoltajalle paikkatilanteesta. Sen sijaan keskustelu etenee työntekijän tietämisen alueelta perheen alueelle. Palveluohjaukselle asetettuja tavoitteita täytetään sekä tarjoamalla perheelle tietoa että kartoittamalla perheen tilannetta. Keskustelun aikana työntekijä saakin hakijaperheestä informaation, joka näyttää ratkaisevan lapsen tulevan hoitoratkaisun.

\section{Aineisto-ote 4}

TT: Joo, minkä ikänen lapsi teillä on hoitoon tulossa?

H: Vuos ja kuukaus.

TT: Joo.

H: Se on niin pieni vielä.

TT: Niin juuri, kyllä.

H: On.
TT: Seki. Se käytännössä sillon tarkottaa sitä että se onki se, oikeestaan perhepäivähoito onki se sitte se hoidon muoto. Jos meijän alueelta lähetään sitä hoitopaikkaa etsimään [---]

Jotta työntekijä pystyy vastaamaan huoltajan kysymykseen, olennaiseksi tiedoksi osoittautuu lapsen ikä. Työntekijälle selviää, että varhaiskasvatuspaikkaa tarvitseva lapsi on vähän yli vuoden ikäinen, mikä ratkaisee hoitopaikan. Voi olettaa, että työntekijällä oli jo heti keskustelun alussa tiedossa vapaiden perhepäivähoitopaikkojen tilanne. Kuitenkin vasta lapsen iän selvittyä hän kertoo, että tämän ikäisen lapsen hoitopaikka on perhepäivähoito. Palveluohjauksen työntekijällä on tietoa alueensa hoitopaikkoihin liittyvistä asioista, huoltajalla lapsen ja perheen tilanteesta. Keskustelussa huoltajan ja työntekijän yhteinen tiedollinen perusta (Lindholm \& Stevanovic, 2016) muodostuu lapsen ikään liittyvästä yhtäläisestä tiedosta (Heritage, 2012), siitä, että yksivuotias lapsi on vielä pieni. Samanmielisyys voi toimia osapuolten välisen tiedollisen epäsymmetrian tasoittajana.

\section{Tietämisen oikeus vanhempien työtilanteesta}

Kuten edellä todettiin, on palveluohjauksessa työntekijän tehtävänä antaa tietoa kunnan varhaiskasvatuspalveluista, mutta pelkästään tiedon omaaminen ei riitä palveluohjauksen tavoitteiden saavuttamiseksi. Neuvontatehtävässä olennaista on myös, että työntekijä saa tietoa asiakkaan tilanteesta (ks. myös HE 80/2015), eli työntekijän tietämisen alueeseen kuuluvista seikoista. Palveluohjauskeskusteluissa työntekijä hakee kysymyksillä tietoa huoltajalta. Kysymyksillä työntekijä voi myös johdatella keskustelun kulkua ja tarkistaa jo olemassa olevan tiedon oikeellisuuden (ks. Raevaara, 2006). Tutkimusaineistossa tuleekin esiin varsin johdonmukainen tulkinta siitä, mikä on työnteki- 
jälle olennaista tietoa ja mihin tietoon hänellä samalla on itsestään selvästi oikeus. Työntekijöiden puheessa tämä tulee esiin muun muassa huoltajille esitetyissä kysymyksissä, kuten seuraavassa:

\section{Aineisto-ote 5}

TT: [---] sä oot hakenu kokopäivähoitoo.

H: Joo.

TT: Ni oletko nyt lähdössä sitten töihin?

Ote on palveluohjauksesta, jossa keskustellaan lapsen siirtymisestä kotihoidosta varhaiskasvatukseen. Työntekijä soittaa huoltajalle tutustuttuaan tämän jättämään päivähoitohakemukseen. Keskustelun alussa hän aloittaa molempien osapuolten tiedossa olevalla asialla pyytäen kuitenkin huoltajaa vahvistamaan asiantilan paikkansapitävyyden esittämällä väitemuotoisen lausuman (Heritage, 2012; Raevaara, 2006, s. 89) siitä, että kyseiselle lapselle on haettu kokopäiväistä varhaiskasvatusta. Tämän jälkeen työntekijä tarkistaa kysymyksellä tiedon paikkansapitävyyden huoltajan työhön siirtymisestä. Työntekijän kysymykset perustuvat hänen tulkintaansa huoltajan tilanteesta ja tietämykseen siitä, mitä tietoja käsiteltävänä olevan asian hoitaminen edellyttää (Raevaara, 2006). Samankaltaisia kysymyksiä esiintyy muissakin aineiston keskusteluissa, joissa kyse on kotihoidosta varhaiskasvatukseen siirtymisestä.

Myös niissä keskusteluissa, jotka liittyvät esimerkiksi hoitopaikan vaihtamiseen ja joissa työntekijällä on jo ilmeisesti tarkempaa tietoa huoltajan työtilanteesta, työhön liittyvät kysymykset ovat tavallisia. Tällöin kysymykset voivat koskea esimerkiksi huoltajien työaikoja, toisen huoltajan työtilannetta tai työmatkaa.
Näissäkin keskusteluissa huoltajan tai huoltajien työhön liittyvät seikat tulkitaan työntekijän tietämisen alueeseen kuuluviksi. Tämä tulkinta ei kehystä vain työntekijöiden kysymyksiä, vaan tulee esiin myös huoltajien selonteoissa. Huoltajat tyypillisesti esittävät selontekoja työstään, vaikka työntekijä ei olisi niistä kysynytkään. Esimerkiksi seuraavassa aineisto-otteessa huoltaja kertoo ensin uudesta työpaikastaan ja tarkoituksestaan siirtyä kotoa työelämään. Työntekijän kysyessä tämän jälkeen perhetilanteesta huoltaja vastaa selittämällä sekä puolisonsa että oman tulevan työaikansa.

\section{Aineisto-ote 6}

H: Elikkä siis kävin työhaastattelussa jo parin viikon sisään koska mulla on edellisestä työstä irtisanomisaika ja minä oon vielä kotihoidon tuella (2) Ja niin tuota, nyt alkas tuossa, lähikaupassa työt ja (1) en tiiä mitä vuoroja siellä on ja millon. Et mitenkä mun pitää tehä (1) mitä mä teen?

TT: Minkäslainen perhetilanne teillä on?

H: Öö, no mies on töissä, joka päivä seittemäst puoli neljään. Ja mulla nyt tulee kaupan aukiolojen mukasesti kaksvuorotyötä.

Edellä olevassa aineisto-otteessa työntekijä siirtää kysymyksellään puheen äidin työn aloituksesta perhetilanteeseen. Huoltajan vastauksesta voi päätellä hänen tulkinneen työntekijän kysymyksen kytkeytyvän aiemmin puhuttuun (Mäntylä, 2006) eli työhön. Tutkimusaineiston palveluohjauskeskusteluja luonnehtiikin niiden keskittyminen huoltajan työhön liittyvien kysymysten tarkasteluun. Työ kehystää sekä työntekijöiden että huoltajien puhetta. Yhtäältä voi ajatella, että subjektiivisen varhaiskasvatusoikeuden rajauksen vuoksi lapsilta, joiden huoltaja on kotona esimerkiksi perhevapaalla tai työttömänä on huoltajien työtilanne tarpeen 
keskustella varhaiskasvatuksen palveluohjauskeskusteluissa. Toisaalta varhaiskasvatukselle sen valtakunnallisessa ohjauksessa annetut merkitykset ovat huomattavasti sen työvoimapoliittista tehtävää laajemmat ja painottavat lapsen etua. Aineistossa työntekijän tietämisen oikeutus rajautuu kuitenkin ennen kaikkea huoltajien työ- tai opiskelutilanteeseen.

\section{Pohdinta}

Tässä artikkelissa tarkasteltiin, millaiseksi työntekijän tietämisen alue muodostuu varhaiskasvatuksen palveluohjauksen puhelinkeskusteluissa. Analysoimme sitä, miten työntekijän tiedollinen asema rakentui vuorovaikutuksessa huoltajan kanssa ja minkä huoltajan omaavan tiedon tulkittiin keskusteluissa kuuluvan myös työntekijälle. Aineiston analyysissa hyödynsimme diskurssianalyyttista tarkastelutapaa, jossa kielenkäyttö ymmärretään toiminnaksi. Tutkimuksen tuloksena esitimme palveluohjauksen työntekijän tietämisen alueen muodostuvan tiedon tarjoamisen, tiedonannon vaiheittaisuuden ja tietämisen oikeutuksen kokonaisuutena.

Yksi palveluohjaukselle annettu lakisääteinen tehtävä on huoltajien informoiminen erilaisista varhaiskasvatuksen vaihtoehdoista ja varhaiskasvatukseen hakemiseen liittyvistä kysymyksistä. Kaikkien tämän artikkelin aineistona toimivien keskustelujen voi nähdä vastaavan tähän tehtävään. Palveluohjauksen työntekijän ammatillisen tietämisen alue muodostui lähtökohtaisesti kunnan varhaiskasvatuspalveluita koskevasta perustiedosta. Tiedon tarjoamisen lähtökohtana olivat usein huoltajien esittämät palveluja koskevat kysymykset, joihin työtekijä tarjosi vastaukset. Tiedon tarjoaminen tuli esille myös työntekijän huoltajalle antamien toimintaohjeiden ja neuvojen muodossa. Kuten asiantuntijan ja asiakkaan välisissä suhteissa laajemmin (ks. Vehviläinen, 2001), myös pal- veluohjauskeskusteluissa neuvo voitiin antaa pyytämättä, vastauksena huoltajan kysymykseen tai täydentämään huoltajan puuttuvaa tietoa. Osa työntekijän ammatillisen tietämisen alueesta oli myös huoltajien ulottuvilla.

Osa työntekijän tietämisestä käsitti asioita, jotka eivät olleet perheiden saatavissa muualta, esimerkiksi tieto vapaista hoitopaikoista. Tällaisessa tilanteessa huoltajille saatettiin antaa/ annettiin tietoa vaiheittain, samalla kun työntekijä kysyi huoltajalta lisätietoa perheen tilanteesta tai muusta asiaan liittyvästä seikasta. Nämä tilanteet ilmensivät Raevaaran (2006) kuvaamaa eri näkökulmien yhteensovittamista asiakkaan asian hoitamiseksi.

Työntekijän tietämisen oikeutus tuli esille siten, että työntekijällä näytti olevan oikeus kysyä ja saada tietoa perheestä tiettyihin asioihin liittyen. Aineistossa nämä asiat käsittelivät erityisesti huoltajien työtilannetta; se osoittautui merkitykselliseksi työntekijän tietämisen alueeksi. Työntekijöiden huoltajien työtilannetta koskevien kysymysten lisäksi huoltajat esittivät selontekoja perheen työtilanteesta, vaikkei työntekijä olisi sitä heiltä kysynytkään (vrt. Mäntylä, 2006). Siten palveluohjauskeskusteluja sävytti vahva työelämäorientoituneisuus. Sen sijaan lapsesta keskusteltiin varsin vähän. Joissain keskusteluissa työntekijä saattoi kysyä lapsen ikää tai huoltaja kuvata jotain lapsen terveyteen liittyvää seikkaa. Muita tietoja lapsesta työntekijät eivät keskusteluissa juuri kysyneet, eivätkä myöskään huoltajat tuoneet esille, vaikka hoitoratkaisun tulisi vastata lapsen tarpeita ja etua.

Artikkelissa työntekijän episteeminen ja deonttinen asemoituminen suhteessa huoltajaan tulee esille etenkin tiedon ja neuvojen tarjoamisessa, mikä osaltaan ilmentää vuorovaikutukseen osallistujien välistä tiedollista epäsym- 
metriaa (myös Alasuutari, 2010). Tiedollinen epäsymmetria loiveni kuitenkin samanmielisyyttä sisältävissä puheenvuoroissa, joissa keskustelijoilla oli yhteinen käsitys puheena olevasta asiasta (esim. Mikkola, 2015) esimerkiksi lapsen ikään liittyen.

Kaikkineen palveluohjauksen työntekijät ovat haastavan tehtävän edessä, kun he yrittävät vastata perheiden tarpeisiin ainakin toisinaan rajallisista varhaiskasvatusresursseista huolimatta ja yhtä aikaa pyrkivät käyttämään resursseja järkevästi. Tämä saattaa ilmetä esimerkiksi tiedonannon vaiheittaisuutena. Tiedon "säännöstely" voi ohjata huoltajaa kohti tietynlaisia lastenhoidon ratkaisuja, sillä huoltajalla ei välttämättä ole yksityiskohtaista tietoa varhaiskasvatuksen järjestämisestä, kuten asiakasmaksusta tai palveluvalikoimasta. Tämän vuoksi huoltajan mahdollisuus valita perheelle sopivin varhaiskasvatusratkaisu voi olla rajattu. Voikin pohtia, toteutuvatko lain tavoitteet, jos palveluohjausta orientoivat ainakin osin kunnan resurssit.

Varhaiskasvatuksen palveluohjauksen ohjeistukset ovat niukat, ja tutkimustietoa on toistaiseksi vähän. Lainsäädäntöön vastaaminen voi olla haastavaa, jos yhtenäistä näkemystä palveluohjauksen tehtävästä ja toteuttamisesta ei ole. Palveluohjauksen kehittämisen kannalta voisikin olla hyödyllistä miettiä, kuinka palveluohjausta kehitetään siten, että myös perheiden ja lasten tarpeet tulevat osaksi ohjauskeskusteluja. Palveluohjaus on yksi muotoutuvista työmuodoista, ja siten jatkossakin olennainen tutkimuskohde palvelun kehittämiseen koulutuksellisten kysymysten kannalta.

Tämä artikkeli on esittänyt tapaustutkimuksen, jolla on omat rajoitteensa. Ensinnäkin puhelinkeskustelut ja niiden tallennukset ovat tyypillisesti lyhyitä, ja tallenteita on suhteelli- sen vähän. Aineiston määrän vuoksi tuloksista tehtävissä päätelmissä on oltava varovainen. Lisäksi rajoituksena voi pitää joidenkin tallenteiden huonoa kuuluvuutta, joka on rajoittanut analyysimahdollisuutta. Aineiston ei voi ajatella kattavan palveluohjauksen keskustelujen koko kenttää, ja on huomioitava, että se on ainakin jossain määrin työntekijöiden valikoimaa. $\mathrm{Mu}-$ kana on epäilemättä myös valikoitumista sen suhteen, miten huoltajat ovat antaneet luvan keskustelujen taltiointiin. Tutkimus on kuitenkin ensimmäinen laatuaan palveluohjauksen institutionaalisesta vuorovaikutuksesta, ja siinä suhteessa sitä voi pitää tärkeänä avauksena palveluohjauksesta käytävään keskusteluun. Palveluohjauskeskustelujen jatkotarkastelu on tärkeää myös kattavammilla tutkimusaineistoilla.

\section{Kirjallisuus}

Alasuutari, M. (2010). Suunniteltu lapsuus. Keskustelut lapsen varhaiskasvatuksesta päivähoidossa. Tampere: Vastapaino.

Butler, C., Potter, J., Danby, S., Emmison, M., \& Hepburn, A. (2010). Advice-implicative interrogatives: Building "client-centred" support in a children's helpline. Social Psychology Quarterly, 73(3), 265-287.

Drew, P., \& Heritage, J. (1992). Analyzing talk at work. An introduction. Teoksessa P. Drew, \& J. Heritage (toim.), Talk at work. Interaction in institutional settings (s. 3-65). Cambridge: Cambridge University Press.

Edwards, D., \& Potter, J. (1992). Discursive Psychology. Beverly Hills, CA: Sage.

Haakana, M., Raevaara, L., \& Ruusuvuori, J. (2001). Lääketieteen termit lääkärin ja potilaan vuorovaikutuksessa. Teoksessa J. Ruusuvuori, M. Haakana, \& L. Raevaara (toim.), Institutionaalinen vuorovaikutus. Keskusteluanalyyttisia tutkimuksia (s. 196-222). Helsinki: Suomalaisen Kirjallisuuden Seura. 
HE 80/2015. Hallituksen esitys eduskunnalle laeiksi varhaiskasvatuslain sekä lasten kotihoidon ja yksityisen hoidon tuesta annetun lain muuttamisesta. (luettu 12.12.2018) https://www.finlex.fi/fi/esitykset/ he/2015/20150080

Hepburn, A., \& Potter, J. (2011). Designing the recipient: Managing advice resistance in institutional settings. Social Psychology Quarterly, 74(2), 216-241. https://doi.org/10.1177/0190272511408055

Heritage, J. (2012). Epistemics in action: Action formation and territories of knowledge. Research on Language \& Social Interaction, 45(1), 1-29. https:// doi.org/10.1080/08351813.2012.646684

Hänninen, K. (2007). Palveluohjaus. Asiakaslähtöistä täsmäpalvelua vauvasta vaariin. Raportteja 20/2007. Helsinki: Stakes, FinSoc. (luettu 12.12.2018) http:// www.julkari.fi/bitstream/handle/10024/75697/R202007-VERKKO.pdf?sequence $=1$ \&isAllowed $=\mathrm{y}$

Jackson, A. Y., \& Mazzei, L. A. (2012). Thinking with theory in qualitative research. Viewing data across multiple perspectives. London: Routledge.

Jokinen, A., Juhila, K., \& Suoninen, E. (2016). Diskurssianalyysi. Teoriat, peruskäsitteet ja käyttö. Tampere: Vastapaino.

Lindholm, C., \& Stevanovic, M. (2016). Sanat. Teoksessa M. Stevanovic, \& C. Lindholm (toim.), Keskustelunanalyysi. Kuinka tutkia sosiaalista toimintaa ja vuorovaikutusta (s. 79-99). Tampere: Vastapaino.

Lindström, J. K., \& Karlsson, S. (2016). Tensions in the epistemic domain and claims of no-knowledge: A study of Swedish medical interaction. Journal of Pragmatics, 106, 129-147. https://doi.org/10.1016/j. pragma.2016.07.003

Mikkola, P. (2015). Kirjallinen teksti ja keskustelijoiden oikeudet: Episteemisten ja deonttisten oikeuksien ilmeneminen esimiehen ja alaisen välisessä kehityskeskustelussa. Prologi, Puheviestinnän vuosikirja 2015. Jyväskylä: Prologos, 75-106.

Molder, H. T. (2015). Discursive Psychology. Teoksessa K. Tracy, C. Ilie, \& T. Sandel (toim.), The International Encyclopedia of Language and Social Interaction (s.1-11). Boston: John Wiley \& Sons.

Mäntylä, M. (2006). Asiakas vastaajana. Myönteiset vastaukset kysymyksiin. Teoksessa M.-L. Sorjonen, \& L. Raevaara (toim.), Arjen asiointia. Keskusteluja Kelan tiskin äärellä (s. 143-169). Helsinki: Suomalaisen Kirjallisuuden Seura.
Opetushallitus (2018). Varhaiskasvatussuunnitelman perusteet. Määräykset ja ohjeet 2018:3a. Helsinki: Opetushallitus.

Potter, J., \& Hepburn, A. 2007. Discursive Constructionism. Teoksessa J. A. Holstein, \& J. F. Gubrium (toim.), Handbook of Constructionist Research (s. 275-293). New York: The Guilford Press.

Raevaara, L. (2006). Kysymykset virkailijan työkaluna. Teoksessa M.-L. Sorjonen, \& L. Raevaara (toim.), Arjen asiointia. Keskusteluja Kelan tiskin äärellä (s. 86-116). Helsinki: Suomalaisen Kirjallisuuden Seura.

Raevaara, L., Ruusuvuori, J., \& Haakana, M. (2001). Institutionaalinen vuorovaikutus ja sen tutkiminen. Teoksessa J. Ruusuvuori, M. Haakana, \& L. Raevaara (toim.), Institutionaalinen vuorovaikutus. Keskusteluanalyyttisia tutkimuksia (s. 11-38). Helsinki: Suomalaisen Kirjallisuuden Seura.

Stevanovic, M. (2013). Deontic right in interaction. A conversation analytic study on authority and cooperation. Publications of the department of social research 10. Helsinki: Helsingin yliopisto.

Stevanovic, M. (2016). Sosiaaliset rakenteet. Teoksessa M. Stevanovic, \& C. Lindholm (toim.), Keskustelunanalyysi. Kuinka tutkia sosiaalista toimintaa ja vuorovaikutusta (s. 200-221). Tampere: Vastapaino.

Stevanovic, M., \& Peräkylä, A. (2012). Deontic authority in interaction: The right to announce, propose, and decide. Research on Language \& Social Interaction, 45(3), 297-321. https://doi.org/10.1080/ 08351813.2012.699260

Tannen, D. (1993). Framing in Discourse. New York: Oxford University Press.

Varhaiskasvatuslaki 540/2018. (luettu 12.12.2018) https://www.finlex.fi/fi/laki/smur/2018/20180540

Vehviläinen, S. (2001). Neuvomisen ongelmia ja ratkaisuja - vertaileva näkökulma. Teoksessa J. Ruusuvuori, M. Haakana, \& L. Raevaara (toim.), Institutionaalinen vuorovaikutus. Keskusteluanalyyttisia tutkimuksia (s. 39-61). Helsinki: Suomalaisen Kirjallisuuden Seura.

Wintermantel, M. (1991). Dialogue between expert and novice: on differences in knowledge and their reduction. Teoksessa I. Markova, \& K. Foppa (toim.) Assymmetries in Dialogue (s. 124-142). Harvester wheatsheaf Barnes \& Noble book. 


\section{Liite 1. Litteraatiomerkinnät}

$\begin{array}{ll}\text { TT } & \text { huoltaja } \\ {[]} & \text { työntekijä } \\ & \text { poistettuja/ muunnettuja tunnistetietoja } \\ (2) & \text { lyhyt tauko } \\ (--) & \text { tauon pituus sekunteina } \\ {[---]} & \text { tekstistä on jätetty osa pois } \\ <>\text { tai }<> & \text { puhenopeuden hidastuminen tai nopeutuminen } \\ \text { [ep } & \text { epäselvää puhetta }\end{array}$

